\title{
Seasonal Incidence of Insect Pests on Rapeseed-Mustard
}

\author{
Deepak Singh Pal ${ }^{1 *}$, D. K. Singh ${ }^{1}$, Arun Kumar ${ }^{2}$ and Sucharu Singh ${ }^{2}$ \\ ${ }^{1}$ Department of Entomology, Chandra Shekhar Azad University of Agricultural and \\ Technology, Kanpur U.P- 208002, India \\ ${ }^{2}$ Department of Entomology, Sardar Vallabhbhai Patel University of Agricultural and \\ Technology, Meerut U.P. - 250110, India \\ *Corresponding author
}

\section{Keywords}

Mustard Sawfly,

Painted Bug,

Mustard Aphid,

Temperature,

Cloudy, Brassica,

$\mathrm{T}-27$

Article Info

Accepted:

22 March 2020

Available Online:

10 April 2020

\section{A B S T R A C T}

Study on seasonal incidence of insect pests on rapeseed-mustard was conducted on the Oilseed Farm Kalyanpur, Kanpur during rabi,2018-19. The occurrence of three major insects were recorded viz., Mustard sawfly Athalialugens proxima Klug which was observed at seedling stage, whereas painted bug Bagrada cruciferarum Kirkaldy was observed at two different crop stages: firstly at seedling stage and secondly at maturity stage and mustard aphid Lipaphiserysimi Kaltenbach appeared from flowering to pod bearing stage of mustard crop. The cloudy weather condition and temperature from $8-32^{\circ} \mathrm{C}$ favoured the insect pests multiplication. Out of the six Brassica species, viz Urvashi, GSC-6, BSH-1, T-27, YST-151 and DRMR IJ-31; T-27 was least attacked by the mustard aphid.

\section{Introduction}

The family brassicaceae (cruciferae) is one of the 10 most economically important plant families consisting of about 3500 species and 360 genera (Warwick et al., 2000). Brassica species play an important role in the world agriculture as oilseed, vegetable, forage, condiments and biodiesel. Brassica crops contribute both to the economies and health of populations (via anti-oxidants, vitamins, anticarcinogenic compounds etc.) around the world.

India account for 19.8 and 9.8 percent of the total acreage and production (USDA 201617). Rapeseed-mustard crops in India are grown in diverse agro climatic conditions ranging from north-eastern / north western hills to down south under irrigated/rainfed, 
timely/late sown, saline soils and mixed cropping. Among various biotic factors responsible for reducing the yield of mustard, insect pests are the major one. According to Bakhetia and Sekhon (1989), 38 insect pests are known to be associated with rapeseedmustard crop in India.

On the basis of their economic importance, the insect pests of mustard crop may be grouped into key pest: aphid, Lipaphiserysimi (Kaltenbach), major pests: sawfly, Athalialugens proxima (Klug), painted bug, Bagradacruciferarum Kirkaldy and leaf miner, Chromatomyia horticola Goureau, minor pests: bihar hairy caterpillar, Spilosoma obliqua Walker, cabbage butterfly, Pieris brassicae Linnaeus, flea beetle, Phyllotreta Cruciferae Goeze and green aphid, Myzus persicae Sulzer, new pests: leaf webber, Crocidolomia binotalis Zeller, borer, Hellulaundalis Fabricius and whitefly, Bemisia tabaci Gennadius.

Among these, aphid, L. erysimi is most important key pest in all the mustard growing regions of the country. The mustard aphid is the most destructive pest in rapeseed mustard. The infestation of mustard aphid occurs in the field from December to February. Both the adults and nymphs of this aphid cause damage to mustard plants from seedling to maturity, but maximum damage is caused at flowering stage (Ahmed and Jalil, 1993).

The aphids suck sap from leaves, flowerbuds, flowers, pod and twigs of the plants. They also secrete sticky honeydew which act as a medium for sooty mold development and reduce the photosynthetic efficiency of the plants. In case of severe infestation, leaves become curled, plant fails to develop pods, the young pods when developed fail to become mature and cannot produce healthy seeds. As a result, plants lose their vigour and growth becomes stunted (Morzia and Huq, 1991).

\section{Materials and Methods}

The experiment was conducted during rabi season 2018-19 at Oilseed Farm, Kalyanpur, Chandra Shekhar Azad University of Agriculture and Technology, Kanpur. Geographically it is situated between $26^{\circ} 21^{\circ}$ east longitude at a height of 125.1 meter above mean sea level. The region is subtropical with semi-arid climate. Six different mustard varieties were selected for recording the population dynamics of mustard aphid; viz. Urvashi, GSC-5, BSH-1, T-27, YST-151, IJ-31.The design used was randomized block design (RBD) under three replications (plot size $4.2 \times 3 \mathrm{~m} 2$ ) on second week of November 2018.

The data on meteorological parameters viz., minimum and maximum temperature $\left({ }^{\circ} \mathrm{C}\right)$, relative humidity $(\%)$, rainfall $(\mathrm{mm})$ and sunshine (hours) of study period, collected from department of Agronomy of the University.

\begin{tabular}{|l|l|l|}
\hline S.No. & $\begin{array}{l}\text { Insect- } \\
\text { pests }\end{array}$ & Mode of observation \\
\hline 1. & $\begin{array}{l}\text { Mustard } \\
\text { sawfly }\end{array}$ & $\begin{array}{l}\text { No. of grubs on 10 randomly } \\
\text { selected plants/plot }\end{array}$ \\
\hline 2. & $\begin{array}{l}\text { Painted } \\
\text { bug }\end{array}$ & $\begin{array}{l}\text { No. of nymph and adults/m } \\
\text { row }\end{array}$ \\
\hline 3. & $\begin{array}{l}\text { Mustard } \\
\text { aphid }\end{array}$ & $\begin{array}{l}\text { No. of aphids on 10 cm } \\
\text { central top twigs of 10 } \\
\text { randomly selected plants per } \\
\text { plot }\end{array}$ \\
\hline
\end{tabular}

\section{Results and Discussion}

Based on regular monitoring of insect pests during rabi 2018-19, three insect pests namely mustard sawfly Athalialugensproxima Klug, painted bug Bagradahilaris Kirkaldy and mustard aphid, Lipaphiserysimi Kalt. were infesting rapeseed mustard at different growth stages. 


\section{Mustard sawfly}

It is obvious from the Table 1 that the incidence of mustard sawfly on Urvashi was recorded as 1.6 grubs/ plant in $45^{\text {th }}$ Standard Meteorological Week (SMW) and found till $48^{\text {th }}$ SMW. The peak population of insect was observed in $46^{\text {th }} \mathrm{SMW}$ as 2.3 grubs/plant. The population of mustard sawfly on GSC-6 was 1.0 grub/plant in $45^{\text {th }}$ SMW. The population of insect increased to a level of 2.3 grubs/ plant in $46^{\text {th }} \mathrm{SMW}$. Thereafter, the population of mustard sawfly declined and was not observed beyond $48^{\text {th }}$ SMW.

The population of mustard sawfly on BSH-1 was recorded from $45^{\text {th }}$ to $48^{\text {th }}$ SMW. Its highest population, 3.6 grubs/plant was observed on $46^{\text {th }}$ SMW. The population of mustard sawfly on YST-151 was observed from $45^{\text {th }}$ to $48^{\text {th }}$ SMW with peak population, 2.6 grubs/plant during $46^{\text {th }}$ SMW. The population of mustard sawfly was not found $49^{\text {th }}$ week onwards. The incidence of mustard sawfly on T-27 was recorded from $46^{\text {th }}$ to $48^{\text {th }} \mathrm{SMW}$. The peak population of this insect, 1.3 grubs/plant was observed in $46^{\text {th }} \mathrm{SMW}$ .The mustard sawfly was observed on DRMR IJ-31 from $45^{\text {th }}$ to $48^{\text {th }}$ SMW. The highest population of mustard sawfly was observed, 2.6 grubs/plant in $46^{\text {th }}$ SMW.

The mustard sawfly appeared at early stage of crop growth numbering from 0.3 to 3.6 grubs/plant on different Brassica spp. during crop season. Mustard sawfly was found attacking Brassica oilseed at early stage of crop growth, which was found in accordance with early records (Manjar, 1996).

The weather conditions influenced the incidence of mustard sawfly in the present studies had the support of studies of the past by several workers (Jat et al., 2006; Singh et al., 2008). The finding of present study suggests that temperature ranging from $26.6^{\circ} \mathrm{C}-28.3^{\circ} \mathrm{C}$ was found conducive for its multiplication.

\section{Painted bug}

It is apparent from the Table 2 that the painted bug was observed on Brassica crops at two distinct phases of crop growth, firstly it appeared at seedling stage and Secondly at pod bearing to maturity stage, skipping the Flowering stage of crop growth. Periodically during First phase the insect was recorded from $45^{\text {th }}$ to $48^{\text {th }}$ SMW, whereas in second phase, it occurred from $8^{\text {th }}$ to $12^{\text {th }} \mathrm{SMW}$.

The population of painted bug on Urvashi ranged from 0.0 to 2.0 bugs/meter row with maximum population 2.6 bugs/meter row in the $46^{\text {th }}$ SMW during early stage of crop growth. During second phase of attack, the population of painted bug varied from 0.6 to $4.0 \mathrm{bugs} / \mathrm{meter}$ row with peak population of 4.0 bugs/meter row in $12^{\text {th }}$ SMW.

The climatic condition prevailed during second phase of attack by painted bug were found to be more favourable than first phase of attack .The population of painted bug on GSC-6 was recorded from $45^{\text {th }}$ to $48^{\text {th }}$ SMW during first phase of attack and it ranged from 0.7 to $2.6 \mathrm{bugs} / \mathrm{meter}$ row with with peak population 2.6 bugs/meter row during $46^{\text {th }}$ and $47^{\text {th }}$ SMW. During second phase of attack, the population of painted bug was observed from $8^{\text {th }}$ to $12^{\text {th }}$ SMW and it varied from 1.0 to 4.5 bugs/meter rows with peak population of 4.5 bugs/meter row in $12^{\text {th }} \mathrm{SMW}$.

The population of painted bug on BSH-1 was recorded from $45^{\text {th }}$ to $48^{\text {th }}$ SMW during first phase of attack and it ranged from 0.3 to 3.6 bugs/meter row with peak population 3.6 bugs/meter rows during $47^{\text {th }}$ SMW. During second phase of attack, the population of painted bug was observed from $8^{\text {th }}$ to $12^{\text {th }}$ SMW and it varied from 1.6 to $5.6 \mathrm{bugs} / \mathrm{meter}$ 
row with peak population of $5.6 \mathrm{bugs} / \mathrm{meter}$ row in $12^{\text {th }} \mathrm{SMW}$.During first phase of attack on YST-151 the population of painted bug was observed from $45^{\text {th }}$ to $48^{\text {th }}$ SMW and it ranged from 1.0 to $3.0 \mathrm{bugs} / \mathrm{meter}$ row with peak population 3.0 bugs/meter row during $47^{\text {th }}$ SMW. The population of painted bug was observed from $8^{\text {th }}$ to $12^{\text {th }}$ SMW during second phase of attack and it varied from 0.3 to 4.3 bugs/meter row with peak population of 4.3 bugs/meter row in $12^{\text {th }} \mathrm{SMW}$. The population of painted bug on T-27 was recorded from $45^{\text {th }}$ to $48^{\text {th }}$ SMW during first phase of attack and it ranged from 0.3 to 2.6 bugs/meter row with peak population 2.6 bugs/meter row during $47^{\text {th }}$ SMW.

During second phase of attack, the population of painted bug was observed from $8^{\text {th }}$ to $12^{\text {th }}$ SMW and it varied from 2.0 to $3.3 \mathrm{bugs} / \mathrm{meter}$ row with peak population of $3.3 \mathrm{bugs} / \mathrm{meter}$ row in $12^{\text {th }}$ SMW. During first phase of attack on DRMR IJ-31 the population of painted bug was observed from $45^{\text {th }}$ to $48^{\text {th }}$ SMW and it ranged from 1.3 to 3.0 bugs/meter row with peak population 3 bugs/meter row during $47^{\text {th }}$ SMW. The population of painted bug was observed from $8^{\text {th }}$ to $12^{\text {th }} \mathrm{SMW}$ during second phase of attack and it varied from 2.0 to 4.2 bugs/meter row with peak population of 4.2 bugs/meter row in $12^{\text {th }}$ SMW. The painted bug is a serious pest of cruciferous plants. This insect was observed as more destructive at the seedling and pod formation stages of mustard crops Vora et al., (1985).

\section{Mustard aphid}

The data regarding population of mustard aphid are given in Table 3 the incidence of mustard aphid was observed from $2^{\text {nd }}$ SMW to $12^{\text {th }}$ SMW on different Brassica spp. Depending upon varying period of flowering of different varieties. Out of the six varieties, the incidence of mustard aphid was first recorded on BSH-1 and YST-151 during the second SMW.

The population of mustard aphid on Urvashi was recorded from $4^{\text {th }}$ to $12^{\text {th }}$ SMW. The peak population of mustard aphid, 79.6 aphids $/ 10 \mathrm{~cm}$ central twig/plant was observed in $8^{\text {th }}$ SMW. The occurrence of mustard aphid on GSC-6 was recorded from $4^{\text {th }}$ to $12^{\text {th }}$ SMW. The peak population of mustard aphid, 80.0 aphids $/ 10 \mathrm{~cm}$ central twig/plant was observed in $8^{\text {th }}$ SMW. The population of mustard aphid on BSH-1 was recorded from $2^{\text {nd }}$ to $11^{\text {th }} \mathrm{SMW}$.

Table.1 Occurrence of mustard sawfly on different Brassica sp. during rabi, 2018-19

\begin{tabular}{|c|c|c|c|c|c|c|c|c|c|c|c|c|}
\hline \multirow{3}{*}{$\begin{array}{l}\text { Standard } \\
\text { Meteoro- } \\
\text { logical } \\
\text { Week } \\
\text { (SMW) }\end{array}$} & \multirow{2}{*}{\multicolumn{6}{|c|}{$\begin{array}{c}\text { No. of sawfly/Plant } \\
\text { Brassica } \text { Spp. }\end{array}$}} & \multicolumn{6}{|c|}{ Weather Parameters } \\
\hline & & & & & & & \multicolumn{2}{|c|}{ Temp $\left({ }^{\circ} \mathrm{C}\right)$} & \multicolumn{2}{|c|}{$\mathbf{R H}(\%)$} & \multirow{2}{*}{$\begin{array}{c}\text { Rainfall } \\
\text { (mm) }\end{array}$} & \multirow{2}{*}{$\begin{array}{l}\text { Sunshine } \\
\text { (Hours) }\end{array}$} \\
\hline & Urvashi & $\begin{array}{c}\text { GSC- } \\
6\end{array}$ & $\begin{array}{c}\text { BSH- } \\
1\end{array}$ & $\begin{array}{l}\text { YST- } \\
151\end{array}$ & $\begin{array}{l}\text { T- } \\
27\end{array}$ & $\begin{array}{c}\text { DRMR } \\
\text { IJ-31 }\end{array}$ & Max. & Min. & Mor. & Eve. & & \\
\hline 45 & 1.6 & 1.0 & 0.6 & 0.3 & 0.0 & 2.0 & 28.3 & 12.8 & 82 & 44 & 0.0 & 6.5 \\
\hline 46 & 2.3 & 2.3 & 3.6 & 2.6 & 1.3 & 2.6 & 29.5 & 10.6 & 84 & 34 & 0.0 & 8.1 \\
\hline 47 & 0.6 & 1.6 & 2.3 & 1.9 & 0.6 & 2.3 & 28.5 & 11.3 & 80 & 34 & 0.0 & 8.7 \\
\hline 48 & 0.3 & 0.3 & 0.6 & 1.0 & 0.3 & 1.6 & 26.6 & 11.6 & 90 & 43 & 0.0 & 5.3 \\
\hline
\end{tabular}


Table.2 Occurrence of painted bug on different Brassica sp. during rabi, 2018-19

\begin{tabular}{|c|c|c|c|c|c|c|c|c|c|c|c|c|}
\hline \multirow{3}{*}{$\begin{array}{l}\text { Standard } \\
\text { Meteorological } \\
\text { Week (SMW) }\end{array}$} & \multirow{2}{*}{\multicolumn{6}{|c|}{ Painted bug/m row }} & \multicolumn{6}{|c|}{ Weather Parameters } \\
\hline & & & & & & & \multicolumn{2}{|c|}{$\operatorname{Temp}\left({ }^{\circ} \mathbf{C}\right)$} & \multicolumn{2}{|c|}{$\mathbf{R H}(\%)$} & \multirow{2}{*}{$\begin{array}{l}\text { Rainfall } \\
\text { (mm) }\end{array}$} & \multirow{2}{*}{$\begin{array}{l}\text { Sunshine } \\
\text { (Hours) }\end{array}$} \\
\hline & Urvashi & GSC-6 & BSH-1 & YST-151 & T-27 & DRMR IJ-31 & Max. & Min. & Mor. & Eve. & & \\
\hline 45 & 1.2 & 1.1 & 0.3 & 1.3 & 0.3 & 1.3 & 28.3 & 12.8 & 82 & 44 & 0.0 & 6.5 \\
\hline 46 & 1.6 & 2.6 & 2.6 & 1.5 & 1.3 & 1.5 & 29.5 & 10.6 & 84 & 34 & 0.0 & 8.1 \\
\hline 47 & 2.0 & 2.6 & 3.6 & 3.0 & 2.6 & 3.0 & 28.5 & 11.3 & 80 & 34 & 0.0 & 8.7 \\
\hline 48 & 0.0 & 0.7 & 1.0 & 1.0 & 0.3 & 1.6 & 26.6 & 11.6 & 90 & 43 & 0.0 & 5.3 \\
\hline 08 & 0.6 & 1.0 & 1.6 & 0.3 & 1.6 & 2.0 & 26.1 & 12.3 & 87 & 50 & 0.0 & 5.5 \\
\hline 09 & 1.4 & 2.3 & 1.7 & 2.6 & 2.0 & 2.3 & 22.6 & 10.5 & 87 & 52 & 9.1 & 4.5 \\
\hline 10 & 2.6 & 4.0 & 3.3 & 3.5 & 2.6 & 2.6 & 27.4 & 12.0 & 79 & 41 & 0.0 & 9.6 \\
\hline 11 & 3.9 & 4.2 & 3.6 & 4.0 & 2.6 & 3.3 & 29.2 & 13.2 & 80 & 38 & 0.0 & 9.0 \\
\hline 12 & 4.0 & 4.5 & 5.6 & 4.3 & 3.3 & 4.2 & 32.2 & 15.8 & 63 & 39 & 0.0 & 10.2 \\
\hline
\end{tabular}

Table.3 Occurrence of mustard aphid on different Brassica sp. during rabi, 2018-19

\begin{tabular}{|c|c|c|c|c|c|c|c|c|c|c|c|c|}
\hline \multirow{3}{*}{$\begin{array}{c}\text { Standard } \\
\text { Meteorological } \\
\text { Week (SMW) }\end{array}$} & \multirow{2}{*}{\multicolumn{6}{|c|}{$\begin{array}{c}\text { No. of aphids } / 10 \mathrm{~cm} \text { central twig } \\
\text { Brassica } \text { Spp. }\end{array}$}} & \multicolumn{6}{|c|}{ Weather Parameters } \\
\hline & & & & & & & \multicolumn{2}{|c|}{$\operatorname{Temp}\left({ }^{\circ} \mathbf{C}\right)$} & \multicolumn{2}{|c|}{ RH(\%) } & \multirow{2}{*}{$\begin{array}{c}\text { Rainfall } \\
\text { (mm) }\end{array}$} & \multirow{2}{*}{$\begin{array}{c}\text { Sunshine } \\
\text { (Hours) }\end{array}$} \\
\hline & Urvashi & GSC-6 & BSH-1 & YST-151 & T-27 & DRMR IJ-31 & Max. & Min. & Mor. & Eve. & & \\
\hline 2 & 0.0 & 0.0 & 0.8 & 0.8 & 0.0 & 0.0 & 21.4 & 7.5 & 87 & 43 & 0.0 & 4.9 \\
\hline 3 & 0.0 & 0.0 & 8.5 & 11.2 & 0.0 & 0.0 & 23.1 & 6.0 & 83 & 39 & 0.0 & 8.0 \\
\hline 4 & 16.0 & 12.4 & 28.9 & 26.6 & 2.0 & 12.2 & 19.6 & 10.6 & 84 & 61 & 13.5 & 3.2 \\
\hline 5 & 38.4 & 42.1 & 58.0 & 44.6 & 7.9 & 19.3 & 21.3 & 8.3 & 85 & 50 & 0.0 & 8.5 \\
\hline 6 & 34.2 & 36.6 & 44.7 & 32.1 & 6.0 & 12.6 & 22.1 & 10.0 & 90 & 55 & 10.5 & 5.1 \\
\hline 7 & 68.5 & 72.2 & 145.4 & 136.8 & 9.2 & 33.8 & 12.3 & 11.6 & 89 & 57 & 1.7 & 5.4 \\
\hline 8 & 79.6 & 80.0 & 261.5 & 211.0 & 11.3 & 190.7 & 26.1 & 12.3 & 87 & 50 & 0.0 & 5.5 \\
\hline 9 & 58.3 & 61.4 & 180.0 & 79.6 & 7.4 & 72.3 & 22.6 & 10.5 & 87 & 52 & 9.1 & 4.5 \\
\hline 10 & 46.0 & 32.2 & 157.6 & 12.4 & 5.7 & 54.9 & 27.4 & 12.0 & 79 & 41 & 0.0 & 9.6 \\
\hline 11 & 12.2 & 18.3 & 22.0 & 0.0 & 0.2 & 20.3 & 29.2 & 13.2 & 80 & 38 & 0.0 & 9.0 \\
\hline 12 & 6.3 & 5.4 & 0.0 & 0.0 & 0.0 & 4.4 & 32.2 & 15.8 & 63 & 39 & 0.0 & 10.2 \\
\hline
\end{tabular}


The maximum population of mustard aphid, 261.5 aphids $/ 10 \mathrm{~cm}$ central twig/plant was observed in $8^{\text {th }} \mathrm{SMW}$.The infestation on BSH1 was comparatively very much greater than other varieties namely, Urvashi, GSC-6, YST-151, T-27, DRMR IJ-31. The incidence of mustard aphid on YST-151 was recorded from $2^{\text {nd }}$ to $10^{\text {th }}$ SMW. The maximum population of mustard aphid, 211.0 aphids $/ 10 \mathrm{~cm}$ central twig/plant was observed in $8^{\text {th }} \mathrm{SMW}$.

The population of mustard aphid on T-27 was recorded from $4^{\text {th }}$ to $11^{\text {th }}$ SMW. The highest population of mustard aphid, 11.3 aphids $/ 10 \mathrm{~cm}$ central twig/plant was observed in $8^{\text {th }}$ SMW .The infestation on T-27 was comparatively very much lesser than other varieties namely, Urvashi, GSC-6, BSH-1, YST-151, DRMR IJ-31. The occurrence of mustard aphid on DRMR IJ-31 was recorded from $4^{\text {th }}$ to $12^{\text {th }} \mathrm{SMW}$. The peak population of mustard aphid, 190.7 aphids $/ 10 \mathrm{~cm}$ central twig/plant was observed in $8^{\text {th }}$ SMW.

Singh et al., (2009) at Kanpur in Uttar Pradesh studied the influence of environmental factors on the population fluctuation of aphid, L. erysimi and reported that the infestation commenced from 3rd week of December $(0.2 \mathrm{aphid} / 10 \mathrm{~cm}$ twig) and reached at peak during 2 nd week of February (292.0 aphids/10 cm twig). During the peak period of aphid population, maximum temperature, minimum temperature and morning relative humidity were 24.7 to $24.8{ }^{\circ} \mathrm{C}, 10.6$ to $14.5{ }^{\circ} \mathrm{C}$ and 83.6 to 94.7 per cent, respectively. Singh and Lal (2012) noticed that the natural appearance of mustard aphid population was started from $2^{\text {nd }}$ week of January during the both year and reached its peak in $8^{\text {th }}$ SMW with $219.07 / 10 \mathrm{~cm}$ terminal shoot and 199.10/10cm terminal shoot during 2009-2010 and 2010-2011. Studies indicated that mustard aphid incidence was higher when maximum and minimum temperature ranged between 9.30 to $25.9^{\circ} \mathrm{C}$ and 8.20 to $25.2^{\circ} \mathrm{C}$, relative humidity during hours 64.75 and 67.6 per cent, rainfall 0.4 and $1.4 \mathrm{~mm}$ and sunshine hours 7.50 and 7.20 during 2009-2010 and 2010- 2011, respectively. Altogether three insect pests viz. mustard sawfly, painted bug and mustard aphid were found attacking at different growth stages of rapeseed and mustard. Mustard sawfly was seen during early stage of crop growth whereas painted bug was observed during two different phases of the crop and mustard aphid was mainly observed during flowering stage and was seen till pod bearing stage.

The incidence of all three insect pests was observed from first appearance till last appearance by taking continuous observations during the crop growth period on different Brassica crops. All the insect pests showed a varying trend with different period of incidence with different peak populations during different Standard Meteorological Weeks. Along with the crop stage and variety, weather conditions had a major role in appearance of insect pests. The cloudy weather condition and temperature from 8$32^{\circ} \mathrm{C}$ favoured the insect pests multiplication. Out of the six Brassica species, viz Urvashi, GSC-6, BSH-1, T-27, YST-151 and DRMR IJ-31; T-27 was least attacked by the mustard aphid. It was evident from the present study that T-27 was comparatively more tolerant to mustard aphid.

\section{References}

Ahmed, T.U. and Jalil, A.F.M.A. (1993) Bangladesh Krishi Onistokari Pokamakor, Jiban Brittanta Nyantron (Bangla). Bangla Academy, Dhaka, pp 381.

Bakhetia, D. R. C. and Sekhon, B. S. (1989) Insect pests and their management rapeseed mustard. Journal of Oilseeds Research, 6(2): 269- 273. 
Manzar, A. (1996) Studies on population dynamics of major insect-pests of Brassica spp. M.Sc Ag Entomology Thesis, Department of entomology, NDUA\&T, Faizabad (U.P): pp. 62.

Morzia, B. and Huq, S.B. (1991) Evaluation of different genotypes of Indian mustard (Brassica juncea) for their reaction to mustard aphid $L$. erysimi. Indian Journal of Agriculture Sciences, 61(3): 210-213.

Jat, D.S., Jat M.C. and Sharma, M.M. (2006) Seasonal incidence of insect pests of Mustard in relation to abiotic factor. Annals Plant Protection Science, 14(2): 475-476.

Singh, A. K. and Lal, M. N. (2012) Population dynamics of mustard aphid, Lipaphiserysimi (kalt.) on mustard in relation to weather parameters. Asian Journal of Biological Science, 7 (2): 216-218.
Singh, R.K. and Verma, R.A. (2008) Comparative study of a bio pesticide with some synthetic pesticides used against Mustard Aphid (Lipaphiseysimi Kalt.). Indian Journal of Agricultural Sciences, 78(9): 821-823.

Singh, R. K., Rajak, S. K. and Verma, R. A. (2009) Influence of abiotic factors on population of Lipaphiserysimi Kalt. Journal of the Entomological Research., 33(2): 129-131.

Vora, V.J., Bharadia, R.H. and Kapadia, M.N. (1985) Pests of rapeseed arid mustard and their control. Pesticides, 29(1): 2840.

Warwick S. I, Francis, A. and La Fleche, J. (2000) Guide to wild germplasm of Brassica and allied crops (tribe Brassiceae, Brassicaceae) $2^{\text {nd }}$ edition Agriculture and Agri-Food Canada Research Branch Publication.

\section{How to cite this article:}

Deepak Singh Pal, D. K. Singh, Arun Kumar and Sucharu Singh. 2020. Seasonal Incidence of Insect Pests on Rapeseed-Mustard. Int.J.Curr.Microbiol.App.Sci. 9(04): 2525-2531. doi: https://doi.org/10.20546/ijcmas.2020.904.302 